\title{
Alkali Activated Paste and Concrete Based on of Biomass Bottom Ash with Phosphogypsum
}

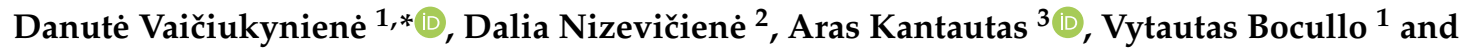 \\ Andrius Kielè ${ }^{1}$ \\ 1 Faculty of Civil Engineering and Architecture, Kaunas University of Technology, \\ LT-44249 Kaunas, Lithuania; vytautas.bocullo@ktu.lt (V.B.); andrius.kiele@ktu.lt (A.K.) \\ 2 Faculty of Electrical and Electronics Engineering, Kaunas University of Technology, Studentu St. 48, \\ LT-51367 Kaunas, Lithuania; dalia.nizeviciene@ktu.lt \\ 3 Faculty of Chemical Technology, Kaunas University of Technology, Radvilènu Pl. 19, \\ LT-50254 Kaunas, Lithuania; aras.kantautas@ktu.lt \\ * Correspondence: danute.vaiciukyniene@ktu.lt or danute.palubinskaite@ktu.lt
}

Received: 9 July 2020; Accepted: 24 July 2020; Published: 28 July 2020

\begin{abstract}
There is a growing interest in the development of new cementitious binders for building construction activities. In this study, biomass bottom ash (BBA) was used as aluminosilicate precursor and phosphogypsum (PG) was used as a calcium source. The mixtures of BBA and PG were activated with the sodium hydroxide solution or the mixture of sodium hydroxide solution and sodium silicate hydrate solution. Alkali activated binders were investigated using X-ray powder diffraction (XRD), $X$-ray fluorescence (XRF) and scanning electron microscopy (SEM) test methods. The compressive strength of hardened paste and fine-grained concrete was also evaluated. After 28 days, the highest compressive strength reached $30.0 \mathrm{MPa}$ - when the BBA was substituted with $15 \%$ PG and activated with $\mathrm{NaOH}$ solution - which is $14 \mathrm{MPa}$ more than control sample. In addition, BBA fine-grained concrete samples based on BBA with $15 \%$ PG substitute activated with $\mathrm{NaOH} / \mathrm{Na}_{2} \mathrm{SiO}_{3}$ solution showed higher compressive strength compered to when $\mathrm{NaOH}$ activator was used $-15.4 \mathrm{MPa}$ and $12.9 \mathrm{MPa}$ respectfully. The $\mathrm{NaOH} / \mathrm{Na}_{2} \mathrm{SiO}_{3}$ activator solution resulted reduced open porosity, so potentially the fine-grained concrete resistance to freeze and thaw increased.
\end{abstract}

Keywords: biomass bottom ash; phosphogypsum; alkali activated fine-grained concrete

\section{Introduction}

In recent years, the amount of biomass bottom ash (BBA) originating from Lithuanian combustion plants is constantly increasing. This type of ash is classified as nonhazardous wastes, so BBA is deposited in local landfills. Consequently, it is very important to reuse ash and to reduce discarding at landfill site. According to Carrasco-Hurtado et al. [1] environmental study showed that the amount of heavy metals in BBA is usually lower than that in fly ash so for that reason it is possible to recycle it in construction materials.

Giergiczny et al. [2] investigated composite cement and concrete containing low-calcium and high-calcium fly ash and granulated blast furnace slag. When large quantities of ash or/and slag were incorporated in the cement system, the properties (e.g., long setting time, low early strength, etc.) of samples were improved. One utilization method for BBA could be the incorporation into construction materials. The chemical and mineral composition of BBA is appropriate for reusing in the production of new, low-carbon building materials. In this way, the replacement of traditional initial material $[3,4]$ such as fly ash or slag in alkali activated materials (AAM) by BBA leads to important environmental benefits [5-7]. As demand for ecological alternatives to Portland cement like alkali 
activated materials (AAM) is growing, there is interest to utilize phosphogypsum (PG) in AAM. AAM binders are aluminosilicate materials like fly ash, slag, red clay that can be activated with an activator solution- $\mathrm{NaOH}, \mathrm{Na}_{2} \mathrm{SiO}_{3}, \mathrm{KOH}$, etc. Concrete produced with these raw materials has shown potential results: the compressive strength of alkali activated fly ash paste reaching over $25 \mathrm{MPa}[8,9]$.

PG can expand the base of the AAM raw materials. Approximately 4.5-5.5 tons of PG is generated per ton of phosphoric acid production using wet process [10]. It is estimated annually 100-280 million metric tons of PG are generated globally. The PG waste is usually stockpiled in landfills. Landfilling stocks results leaching, and hazardous constituents get into groundwater and underlying soils [11]. Pérez-López et al. investigated PG deposited over Tinto river saltmarshes for 40 years until 2010. Study have shown the high potential of contamination of the whole PG stack, including those stack zones that were restored and supposedly should have stop leaching of toxic solutions [12].

Previous studies [13-17] show interest in using PG or gypsum in AMMs. Multiple studies have investigated the optimum amount of gypsum compounds and it was determined that the optimal amount of $\mathrm{CaSO}_{4}$ in alkali activated systems is close to $10 \%$ wt $[13,14]$. Gypsum takes significant part in the activation processes-it completely dissolves and participates in solid product formation. In the alkali's activation reactions PG is a supplier of $\mathrm{SO}_{4}{ }^{2-}$ and $\mathrm{Ca}^{2+}$ ions enhancing the formation of secondary reaction products. When PG is present, portlandite and ettringite initially forms after dissolution form in AAM system. The hardened AAM consists mainly of amorphous hydration products, intermixed with thenardite and minor amounts of secondary gypsum. The incorporation of PG results in shorter initial setting time, but longer final setting time. There is significant increase of compressive strength when activator is $\mathrm{NaOH}$ [13]. The compressive strength development can be attributed to lower porosity $[13,14]$. PG decreases of $\mathrm{Ca} / \mathrm{Si}$ ratios in the $\mathrm{C}-\mathrm{A}-\mathrm{S}-\mathrm{H}$ gels and it could be the reason of a higher polymerized network [13]. The AAM samples with PG inclusion exhibited an average of 1.2 times greater residual strength than samples without PG, after being treated at 400 , 600,800 and $1000{ }^{\circ} \mathrm{C}$ temperatures [15]. Boonserm et al. [16] had found that the additive of flue gas desulfurization gypsum significantly improved the geopolymerization of the mixtures of bottom ash and fly ash. The compressive strength of samples increased too in that samples were up to $10 \%$ of gypsum was used. This increase is explained with the formation of additional amount of CSH. Similar results gave Khater et al. [17]. A 10\% PG additive improved samples mechanical properties and microstructure. Samples were formed from the fly ash, PG and cement kiln dust mixtures. Rashad et al. [14] investigated the alkali activated fly ash and PG. When $5 \%$ or $10 \%$ of semi hydrate PG was incorporated in the system, the mechanical properties, improvement was detected. Chang et al. [18] investigated the influence of phosphoric acid and gypsum on the sodium silicate-based alkali-activated slag pastes. It was determined that the addition of phosphoric acid acted as a retarder.

In previous already published papers, alkali activated systems based on fly ash or fly ash and bottom ash with phosphogypsum were investigated. In this work, only biomass bottom ash was used as an aluminosilicate source. Some amount of BBA was substituted with PG. Both (BBA and PG) are local availability byproducts. The aim of this work is to investigate alkali activated paste and fine-grained concrete with BBA and PG, and to describe the effect of PG on the properties of newly formed AAM systems. Two types of alkali activators were used: $\mathrm{NaOH}$ solutions and the mixtures made from $\mathrm{NaOH}$ solution and sodium silicate hydrate (WG).

\section{Methodology}

\subsection{The Characterization of Raw Materials and the Mixing Composition of Alkali Activated Biomass Bottom Ash Pastes and Concretes}

In this study, the precursor was made from biomass bottom ash (BBA) which was obtained from the combustion plant located in Lithuania. First, this BBA was dried at $100{ }^{\circ} \mathrm{C}$ temperature for $24 \mathrm{~h}$ and then it was milled in ball mill. 
The PG used in this work had $\alpha$ hemihydrate type. It is the waste product of orthophosphoric acid production. PG is formed by the reaction of sulfuric acid from natural apatite according this Equation (1) [19]:

$$
\mathrm{Ca}_{5}\left(\mathrm{PO}_{4}\right)_{3} \mathrm{~F}+5 \mathrm{H}_{2} \mathrm{SO}_{4}+2.5 \mathrm{H}_{2} \mathrm{O}=3 \mathrm{H}_{3} \mathrm{PO}_{4}+5 \mathrm{CaSO}_{4} \cdot 0.5 \mathrm{H}_{2} \mathrm{O}+\mathrm{HF} ;
$$

The powder of PG was taken from the conveyor belt of waste removal and dried at $100 \pm 5^{\circ} \mathrm{C}$ temperature.

According to SEM analysis the BBA particles have irregular shape with angular morphologies (Figure 1a). Microscopic analysis showed that semihydrate phosphogypsum crystals are of dense structure and irregularly shaped parallelepipeds (Figure 1b).

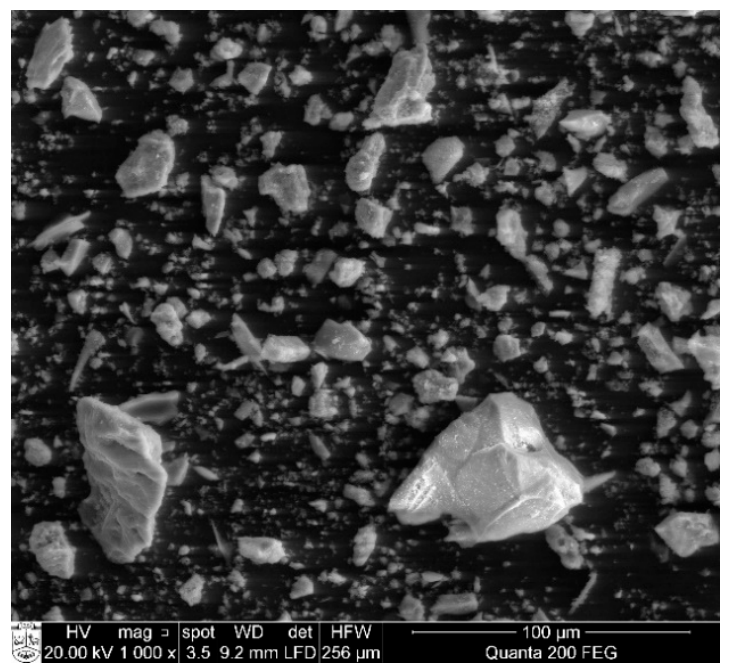

(a)

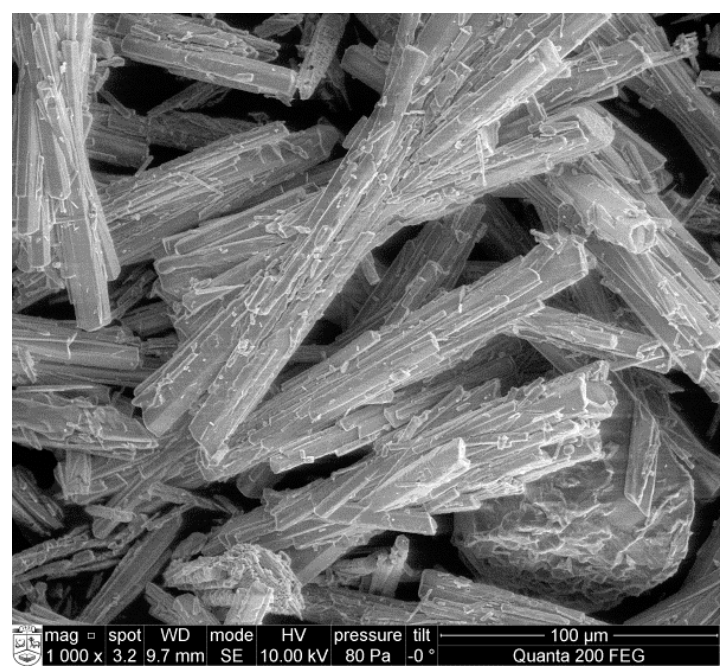

(b)

Figure 1. Microstructure of (a) biomass bottom ash and (b) phosphogypsum.

The particle size distribution for BBA is presented in Figure 2a. The particles size is in wide range from $0.9 \mu \mathrm{m}$ to $460 \mu \mathrm{m}$. The PG particles are finer (Figure 2b) and they are in the range from $0.8 \mu \mathrm{m}$ to $38 \mu \mathrm{m}$. The specific surfaces areas according to Blaine for PG is $201 \mathrm{~m}^{2} / \mathrm{kg}$ and for BBA is $396 \mathrm{~m}^{2} / \mathrm{kg}$.

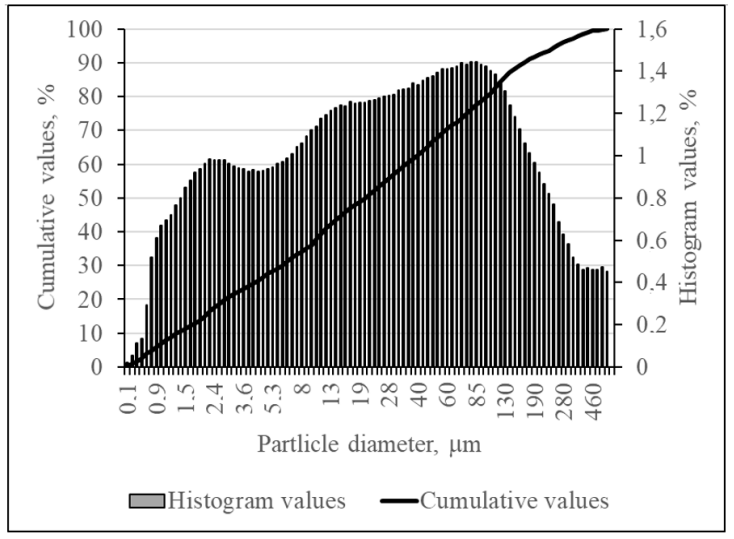

(a)

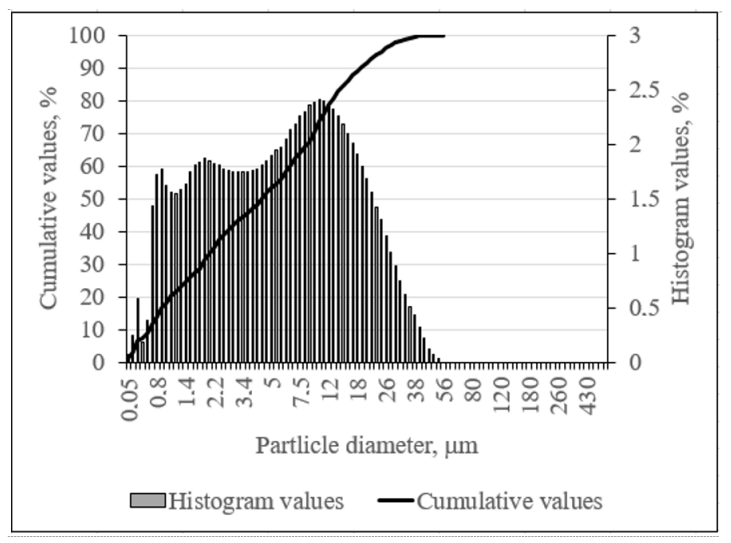

(b)

Figure 2. Granulometric composition of biomass bottom ash (a) and phosphogypsum (b).

The mean diameter of PG particles is $74.7 \mu \mathrm{m}$ and for the particles of BBA is $58.6 \mu \mathrm{m}$. 
The XRD analysis showed that in BBA dominated quartz, anorthoclase, gehlenite and calcium hydroxide with small amounts of calcium carbonate calcium oxide and magnesium oxide (Figure 3a). BBA has semi-amorphous semi-crystalline structure with a broad peak close to silica [20].

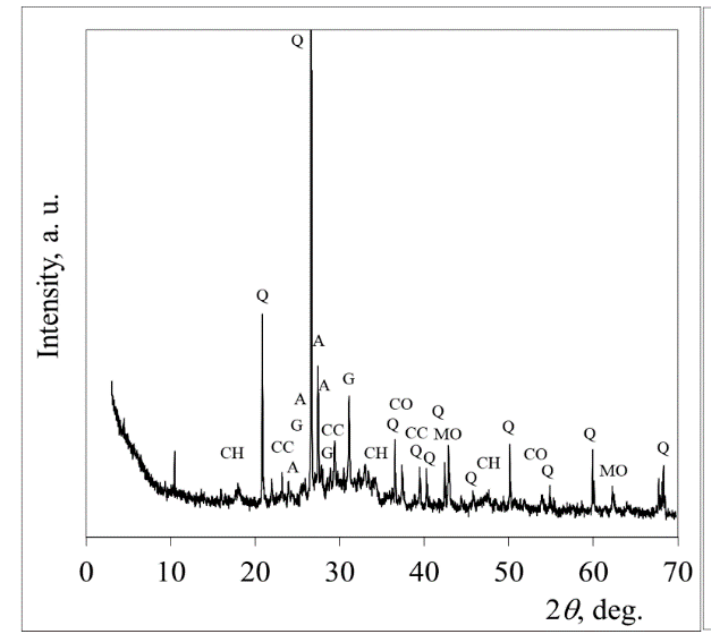

(a)

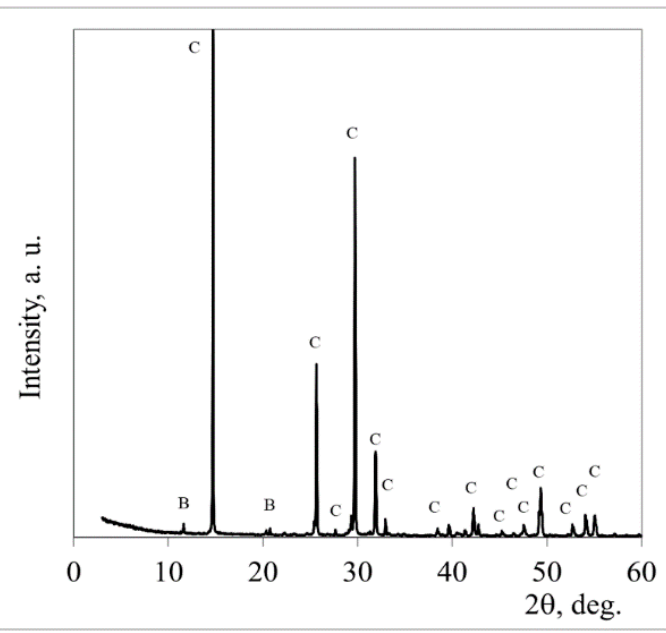

(b)

Figure 3. The mineral composition (XRD analysis) of (a) biomass bottom ash and (b) phosphogypsum. Notes: Q—quartz, $\mathrm{SiO}_{2}$ (77-1070); $\mathrm{CH}$-calcium hydroxide, $\mathrm{Ca}(\mathrm{OH})_{2}$ (84-1271); $\mathrm{CC}$-calcium carbonate, $\mathrm{Ca}(\mathrm{CO})_{3}$ (72-1652); A-anorthoclase, $(\mathrm{Na}, \mathrm{K})\left(\mathrm{Si}_{3} \mathrm{Al}\right) \mathrm{O}_{8}$ (75-1631); G-gehlenite, $\mathrm{Ca}_{2} \mathrm{Al}\left(\mathrm{AlSiO}_{7}\right)$ (79-2421); $\mathrm{CO}$ - calcium oxide, $\mathrm{CaO}$ (4-777); $\mathrm{MO}$-magnesium oxide, $\mathrm{MgO}$ (78-430); C—bassanite, $\mathrm{CaSO}_{4} \cdot 0.5 \mathrm{H}_{2} \mathrm{O}(33-310) ; \mathrm{B}$-brushite, $\mathrm{CaPO}_{3}(\mathrm{OH}) \cdot 2 \mathrm{H}_{2} \mathrm{O}(11-293)$.

In the mineral composition of $\mathrm{PG}$, according to $\mathrm{XRD}$ analysis (Figure $3 \mathrm{~b}$ ), dominated bassanite $\left(\mathrm{CaSO}_{4} \cdot 0.5 \mathrm{H}_{2} \mathrm{O}\right)$ and a small amount of brushite $\left(\mathrm{CaPO}_{3}(\mathrm{OH}) \cdot 2 \mathrm{H}_{2} \mathrm{O}\right) \cdot \mathrm{PG}$ exhibit well definite crystalline structure [21].

This byproduct of biomass combustion in power plants (BBA) has the relatively high calcium, silicon and alkali contents (Table 1).

Table 1. Chemical composition of initial materials, wt $\%$.

\begin{tabular}{cccccccccccccc}
\hline & $\mathrm{CaO}$ & $\mathrm{SiO}_{2}$ & $\mathrm{Na}_{\mathbf{2}} \mathbf{O}$ & $\mathrm{Al}_{\mathbf{2}} \mathbf{O}_{\mathbf{3}}$ & $\mathbf{M n O}$ & $\mathbf{M g O}$ & $\mathbf{K}_{\mathbf{2}} \mathbf{O}$ & $\mathrm{Fe}_{\mathbf{2}} \mathbf{O}_{\mathbf{3}}$ & $\mathbf{P}_{2} \mathrm{O}_{5}$ & $\mathrm{TiO}_{2}$ & $\mathbf{S O}_{3}$ & $\mathbf{F}$ & Other \\
\hline BBA & 49.0 & 22.4 & 0.28 & 2.51 & 0.30 & 8.29 & 8.69 & 2.18 & 5.05 & 0.33 & 0.58 & - & 0.39 \\
PG & 38.60 & 0.37 & - & 0.13 & - & 0.04 & - & 0.03 & 0.81 & - & 53.48 & 0.14 & 6.4 \\
\hline
\end{tabular}

According to the chemical composition of the $\mathrm{PG}, \mathrm{CaO}$ and $\mathrm{SO}_{3}$ are the major components of this material (Table 1). There is some amount of acidic impurities such as $\mathrm{P}_{2} \mathrm{O}_{5}-0.81 \%$; including water-soluble $-0.10 \%$ and $\mathrm{F}-0.14 \%$, which make PG difficult to reuse. Loss on ignition was $6.4 \%$. The $\mathrm{pH}$ of the water suspension-4.7.

Two types of alkali activators were used (Table 2). The first type was sodium hydroxide solution made with commercial $\mathrm{NaOH}$ pellets (analytical grades). The second one was made from the mixture of $\mathrm{NaOH}$ solution and the sodium silicate hydrate (WG) solution (silicate modulus 3.0, concentration 36\%). 
Table 2. The mixing composition of alkali activated biomass bottom ash pastes.

\begin{tabular}{cccccccc}
\hline Samples & $\mathbf{B B A}, \mathbf{g}$ & $\mathbf{P G}, \mathbf{g}$ & $\mathbf{W G}, \mathbf{g}$ & $\mathbf{H}_{\mathbf{2}} \mathbf{O}, \mathbf{g}$ & $\mathbf{N a O H}, \mathbf{g}$ & $\mathbf{S i O}_{\mathbf{2}} / \mathbf{A l}_{\mathbf{2}} \mathbf{O}_{\mathbf{3}}$ & $\mathbf{S i O}_{\mathbf{2}} / \mathbf{N a}_{\mathbf{2}} \mathbf{O}$ \\
\hline PG 0-2 & 100 & 0 & - & 23 & 20.1 & 12.0 & 2 \\
PG 5-2 & 95 & 5 & - & 28 & 19.9 & 12.0 & 2 \\
PG 10-2 & 90 & 10 & - & 29 & 18.8 & 12.0 & 2 \\
PG 15-2 & 85 & 15 & - & 30 & 17.8 & 12.0 & 2 \\
PG 20-2 & 80 & 20 & - & 30 & 16.7 & 12.0 & 2 \\
PG 25-2 & 75 & 25 & - & 30 & 15.7 & 12.0 & 2 \\
PGWG 0-2 & 100 & 0 & 20.0 & 23 & 24.5 & 14.8 & 2 \\
PGWG 5-2 & 95 & 5 & 15.8 & 28 & 22.6 & 14.3 & 2 \\
PGWG 10-2 & 90 & 10 & 14.0 & 29 & 21.2 & 14.2 & 2 \\
PGWG 15-2 & 85 & 15 & 15.7 & 30 & 20.5 & 14.6 & 2 \\
PGWG 20-2 & 80 & 20 & 16.5 & 30 & 19.7 & 14.9 & 2 \\
PGWG 25-2 & 75 & 25 & 19.5 & 30 & 19.4 & 15.6 & 2 \\
PG 0-3 & 100 & 0 & - & 23 & 13.0 & 12.0 & 3 \\
PG 5-3 & 95 & 5 & - & 29 & 12.4 & 12.0 & 3 \\
PG 10-3 & 90 & 10 & - & 30 & 11.7 & 12.0 & 3 \\
PG 15-3 & 85 & 15 & - & 30 & 11.1 & 12.0 & 3 \\
PG 20-3 & 80 & 20 & - & 30 & 10.4 & 12.0 & 3 \\
PG 25-3 & 75 & 25 & - & 30 & 9.8 & 12.0 & 3 \\
PGWG 0-3 & 100 & 0 & 6.4 & 23 & 13.0 & 13.3 & 3 \\
PGWG 5-3 & 95 & 5 & 7.1 & 27 & 12.4 & 13.5 & 3 \\
PGWG 10-3 & 90 & 10 & 6.0 & 28 & 11.7 & 13.3 & 3 \\
PGWG 15-3 & 85 & 15 & 7.3 & 30 & 11.1 & 13.7 & 3 \\
PGWG 20-3 & 80 & 20 & 7.6 & 30 & 10.4 & 13.9 & 3 \\
PGWG 25-3 & 75 & 25 & 9.7 & 30 & 9.8 & 18.4 & 3 \\
\hline
\end{tabular}

Paste samples size was $20 \times 20 \times 20 \mathrm{~mm}$; their composition is given in Table 2. The BBA was substituted for PG at various amounts: $5 \%, 10 \%, 15 \%, 20 \%$ and $25 \%$. The ratio of water and solid materials $(\mathrm{BBA}+\mathrm{PG}$ ) in the mixtures was regulated and ranged from 0.23 to 0.30 . First, dry components were thoroughly mixed. Then, the mixtures were filled with the solutions of alkali activator (Table 2). These solutions were prepared by dissolving $\mathrm{NaOH}$ in water. When the complex alkali activator was used WG solution was filled to sodium hydroxide solution.

The total hydration duration was 28 days. The first day samples hydrated in room temperature, the second day at $60{ }^{\circ} \mathrm{C}$ temperature-and for the remaining 26 days, in room temperature again. All this time samples were covered with polyethylene covering materials which protect the samples from dehydration.

The sand from Kvesai quarry (Lithuania) was used as fine aggregate to produce alkali activated concrete samples the $0 / 4$ fraction sand. The particle density of sand was $2.65 \mathrm{Mg} / \mathrm{m}^{3}$. The amount of initial materials for concrete samples is shown in Table 3.

Table 3. Mixing composition of alkali activated biomass bottom ash concrete, $\mathrm{g}$.

\begin{tabular}{ccccccc}
\hline \multirow{2}{*}{ Ingredients } & \multicolumn{3}{c}{ The Activation with NaOH } & \multicolumn{2}{c}{$\begin{array}{c}\text { The Activation with } \mathbf{N a O H}+ \\
\mathbf{N a}_{\mathbf{2}} \mathbf{O n S i O}_{\mathbf{2}}-\mathbf{m H}_{\mathbf{2}} \mathbf{O}\end{array}$} \\
\cline { 2 - 7 } & CPG 0-3 & CPG 15-3 & CPG 20-3 & CPWG 0-3 & CPWG 15-3 & CPWG 20-3 \\
\hline BBA & 450 & 383 & 360 & 450 & 383 & 360 \\
PG & 0 & 67.5 & 90 & 0 & 67.5 & 90 \\
Sand 0/4 & 1350 & 1350 & 1350 & 1350 & 1350 & 1350 \\
NaOH & 58.5 & 49.7 & 46.8 & 58.5 & 49.7 & 46.8 \\
Water glass & 0 & 0 & 0 & 28.8 & 32.9 & 34.2 \\
Water & 210 & 210 & 210 & 200 & 200 & 200 \\
\hline
\end{tabular}

The compressive strength of hardened AAM paste was evaluated after 7 and after 28 days. To perform the test a hydraulic press ToniTechnik 2020 was used. The compressive strength of samples 
was determined in accordance with EN 196-1:2005. At least of three samples were tested of each type and the Sample Standard Deviation (SSD) was calculated according to Equation (2):

$$
S S D=\sqrt{\frac{\sum(x-\bar{x})^{2}}{(n-1)}} ;
$$

where, $x$ takes on each value in the set; $\bar{x}$ is the average (statistical mean) of the set of values; $n$ is the number of values.

\subsection{The Experimental Techniques}

The mineral composition of initial materials and AAM hardened pastes was carried out by using X-ray powder diffraction analysis. Data were collected by DRON-6 X-ray diffractometer with Bragg-Brentano geometry using Ni-filtered $\mathrm{Cu} \mathrm{K} \alpha$ radiation and graphite monochromator, operating with the voltage of $30 \mathrm{kV}$ and emission current of $20 \mathrm{~mA}$. The step-scan covered angular range of 2-70 in steps of $2=0.02^{\circ}$. The powder X-Ray diffraction patterns were identified with references available in PDF-2 data base [22].

The chemical composition of BBA and PG was evaluated by using XRF analysis. For this purpose, a Bruker X-ray S8 Tiger WD using a rhodium (Rh) tube, an anode voltage Ua up to $60 \mathrm{kV}$ and an electric current I up to $130 \mathrm{~mA}$ were used. The compressed samples were measured in a helium atmosphere [23]. The hydration water (loss on ignition, \%) in phosphogypsum was calculated after heating the material at the temperature $400{ }^{\circ} \mathrm{C}$. The $\mathrm{pH}$ phosphogypsum was measured with the AD8000 professional multi-parameter $\mathrm{pH}-\mathrm{ORP}-\mathrm{C}$ to $16.00 \mathrm{pH}$, a resolution of $0.01 \mathrm{pH}$ and an accuracy of $\pm 0.01 \mathrm{pH}$. The $\mathrm{pH}$ measurements of water suspensions were conducted when the ratio of water (W) and solid material (S) W/S was 10.

Microstructure investigation of BBA, PG and hardened pates was performed using a high-resolution scanning electron microscope ZEISS EVO MA10 [24]. The resolution of the images (of secondary electrons in a high vacuum) of this microscope is at least $3 \mathrm{~nm}$ with $30 \mathrm{kV}$ and at least $10 \mathrm{~nm}$ with $3 \mathrm{kV}$. In the performed analysis, the acceleration voltage was $5 \mathrm{kV}$.

A laser particle size analyzer (CILAS 1090 LD) was used for the evaluation of the particle size of the BBA and PG. The distribution of solid particles in the air stream was $12 \mathrm{wt} \%-15 \mathrm{wt} \%$. Compressed air (2500 mbar) was used as a dispersing phase [25].

The compressive and flexural strength of hardened AAM paste and fine-grained concrete samples were determined by using hydraulic press Toni Technik 2020 according to the EN 196-1. The size of hardened AAM paste samples was $20 \times 20 \times 20 \mathrm{~mm}$. Fine-grained concrete samples were $40 \times 40 \times 160 \mathrm{~mm}$ prisms. For each data point at least tree samples were tested. The compressive strength of hardened AAM paste was evaluated after 2 and 28 days of hydration. The mechanical properties of fine-grained concrete samples were tested after 7 and 28 days.

The total and open porosity of alkali activated fine-grained concrete samples was evaluated by water absorption according to Skripkiunas et al. [26].

\section{Results and Discussion}

The compressive strength of alkali-activated BBA samples is shown in Figure 4. There are two types of samples: one type of hardened AAM pastes was alkali activated by using $\mathrm{NaOH}$ solutions and the mixture of $\mathrm{NaOH}$ and sodium silicate hydrate solutions was used in the second type of samples. When $\mathrm{SiO}_{2} / \mathrm{Na}_{2} \mathrm{O}$ molar ratio was 2 the samples containing $20 \%$ PG substitute had the highest compressive strength. In this case compressive strength reached $24.3 \mathrm{MPa}$ and precursors were alkali activated with $\mathrm{NaOH}$ solutions (Figure 4a). Similar values of compressive strength (23.0 $\mathrm{MPa}$ ) were obtained for that samples which were activated with the mixtures of $\mathrm{NaOH}$ and sodium silicate hydrate solutions. In this case the optimal content of PG substituting was 15\% (by mass of BBA). In all investigated cases (Figure 4a) the substitution of BBA to PG had gains in compressive strength. 
This substitution is recommended not to exceed $25 \%$. Similar compressive strength (25.83 MPa) had geopolymer samples formed with circulating fluidized bed combustion coal bottom ash according to Topçu et al. [27].

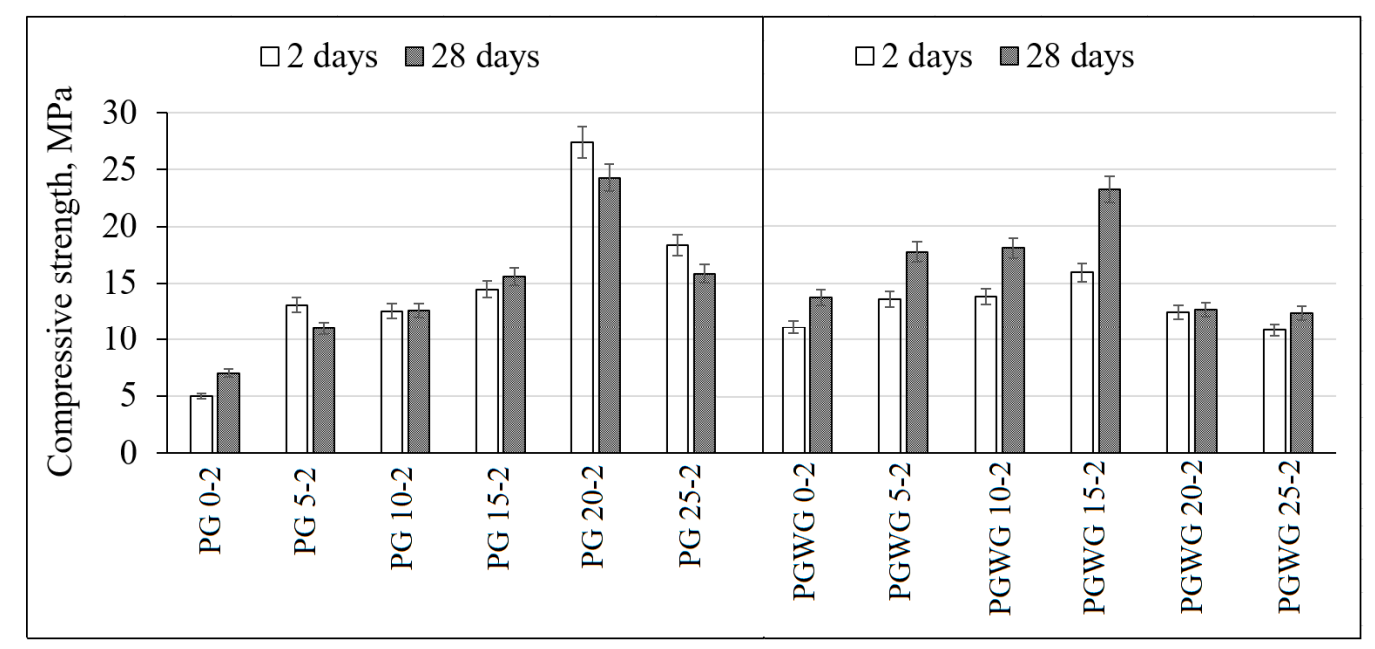

(a)

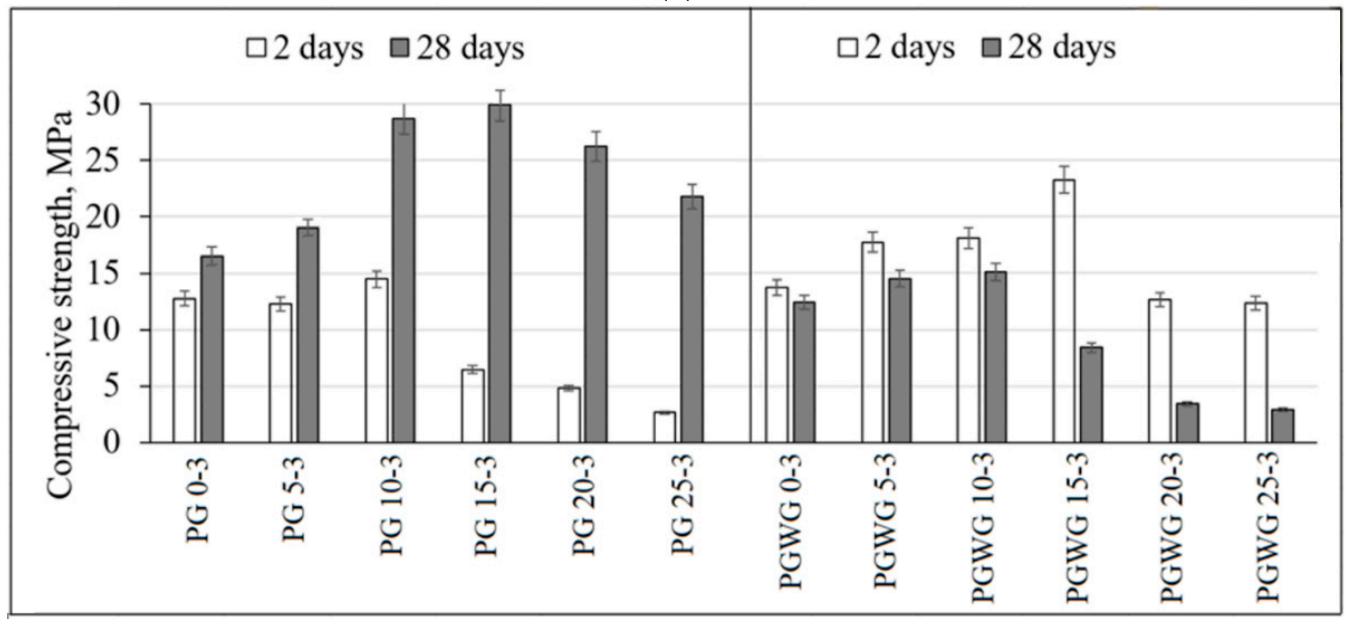

(b)

Figure 4. Compressive strength of alkali-activated biomass bottom ash pastes when $\mathrm{SiO}_{2} / \mathrm{Na}_{2} \mathrm{O}$ molar ratio is (a) 2 and (b) 3 (Table 2).

Figure $4 \mathrm{~b}$ shows the compressive strength of the alkali activated BAA paste with $\mathrm{SiO}_{2} / \mathrm{Na}_{2} \mathrm{O}$ molar ratio 3. The positive effect was detected in this case. In the PG 15-3 samples with the alkali activator of $\mathrm{NaOH}$ solutions the highest compressive strength reached 30.0 MPa after 28 days. By using the same molar ratio but as alkali activator the mixture of $\mathrm{NaOH}$ and sodium silicate hydrate solutions was the compressive strength was reached $23.0 \mathrm{MPa}$ after 7 days of hardening. After longer duration (28 days) of hardening, the reduction was observed of more than 3 times of compressive strength (8.0 MPa). This reduction of compressive strength may be explained by the fast alkali reactions resulted in quick strength gain after 2 days. This gain should be due the increase of gel like matrix. After 28 days the structure samples showed cracks on the surface which could be caused by the drying shrinkage (Figure 4b) [28]. In all investigated cases the use of calcium promoter such as PG which substituted BBA had positive effect to compressive strength gain. After 28 days the compressive strength was higher than compressive strength of reference samples. Similar results related with positive effect of calcium promoters in bottom ash geopolymer fine-grained concrete report Hanjitsuwanet al [29]. 
The mineral composition of alkali activated biomass bottom ash is shown in Figure 5. The X-ray diffraction study is carried out only on the 8 pastes because they are the ones that have shown the highest compressive strength values. The reference compositions were investigated as well. In all X-ray diffraction patterns it is possible to detect quartz and calcium hydroxide which left unreacted from BBA. During alkali reactions calcium silicate hydrate, calcium aluminum oxide hydroxide hydrate, sodium aluminum silicate hydrate formed. When PG was incorporated in the system, additional mineral calcium aluminum hydroxide hydrate formed (PG 20-2, PGWG 15-2, PG 15-3 and PGWG 15-3). The crystal phases remained the same in all samples and it did not depend on the molar $\mathrm{SiO}_{2} / \mathrm{Na}_{2} \mathrm{O}$ ratios which were used in this work. By using lower $\mathrm{SiO}_{2} / \mathrm{Na}_{2} \mathrm{O}$ molar ratio $\left(\mathrm{SiO}_{2} / \mathrm{Na}_{2} \mathrm{O}=2\right)$ the higher amount of alkali had an impact on the formation of $\mathrm{Na}_{2} \mathrm{CO}_{3}\left(\mathrm{H}_{2} \mathrm{O}\right.$ ) (without PG) and $\mathrm{Na}_{2} \mathrm{SO}_{4}$ (with PG). The formation of $\mathrm{Na}_{2} \mathrm{CO}_{3}\left(\mathrm{H}_{2} \mathrm{O}\right)$ had negative affect on the development of compressive strength [30]. When PG was inserted in the alkali activated BBA, PG reacted with $\mathrm{NaOH}$ and this reaction products $\mathrm{Na}_{2} \mathrm{SO}_{4}$ with $\mathrm{Ca}(\mathrm{OH})_{2}$ were (Figure 5a). During hydration process, $\mathrm{Na}_{2} \mathrm{SO}_{4}$ is an effective activator for alkali activated binders [31]. Sodium sulfate could motivate the formation of calcium aluminum silicate hydrate and calcium silicate hydrate. As seen in Figure $5 \mathrm{a}, \mathrm{b}$, the main peak of calcium silicate hydrate is more intensive in the samples where PG was incorporated.

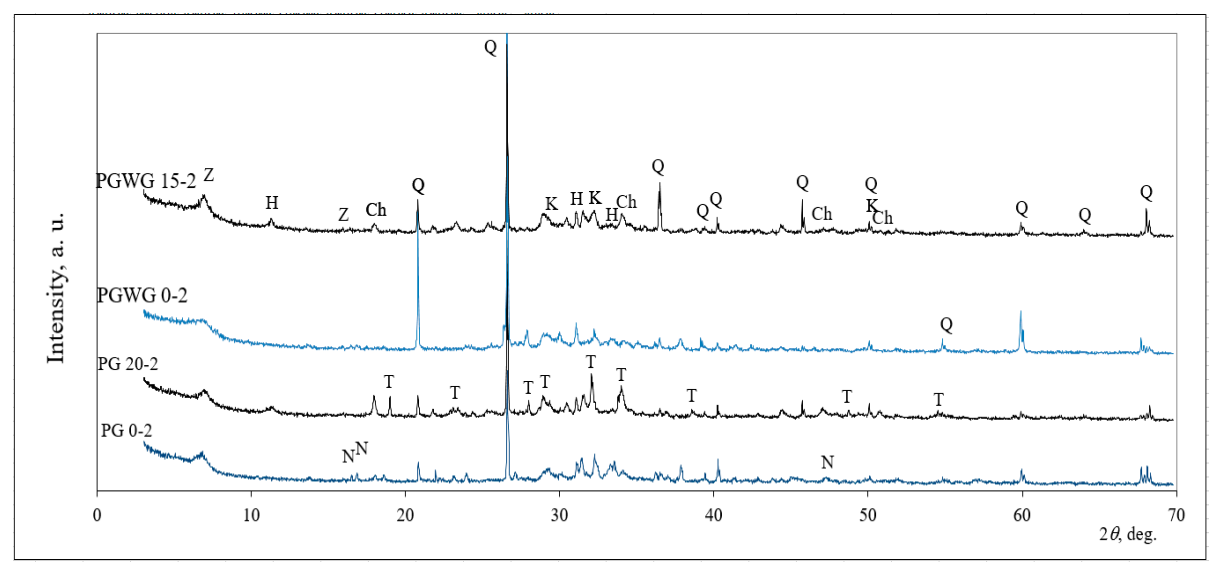

(a)

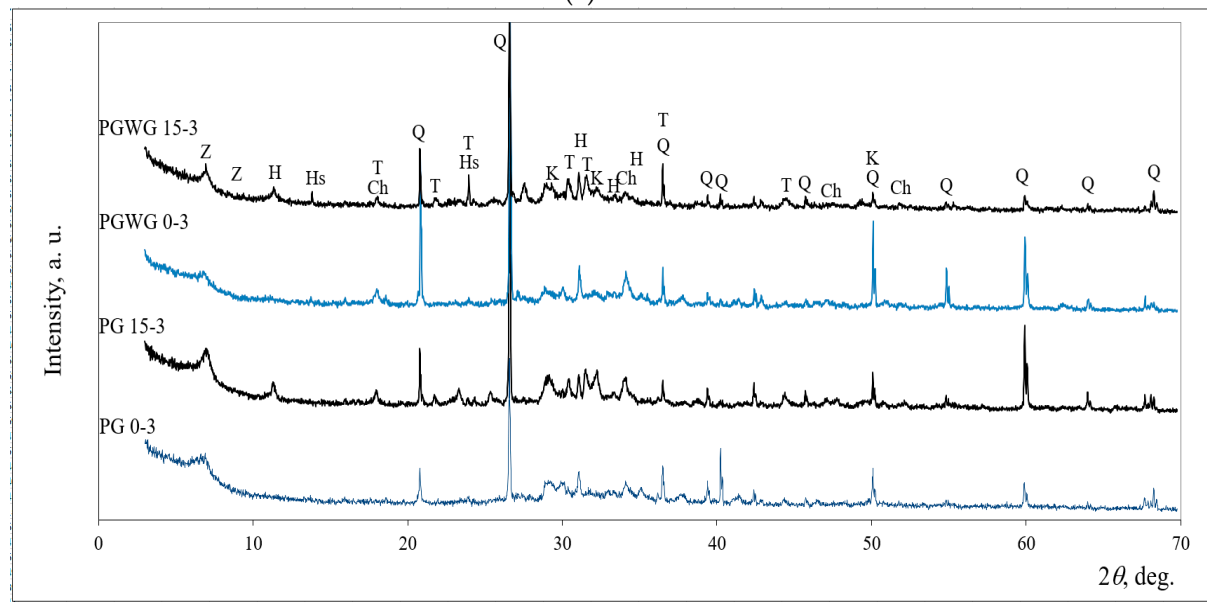

(b)

Figure 5. X-ray diffraction patterns of alkali activated biomass bottom ash when $\mathrm{SiO}_{2} / \mathrm{Na}_{2} \mathrm{O}$ molar ratio is (a) 2 and (b) 3. Notes: Q-quartz, $\mathrm{SiO}_{2}$ (83-2465); $\mathrm{Ch}$-calcium hydroxide, $\mathrm{Ca}(\mathrm{OH})_{2}$ (84-1268); $\mathrm{K}$-calcium silicate hydrate, $\mathrm{Ca}_{1.5} \mathrm{SiO}_{3.5} \times \mathrm{H}_{2} \mathrm{O}$ (33-306); $\mathrm{T}$-thenardite $\mathrm{Na}_{2} \mathrm{SO}_{4}$ (74-2036); $\mathrm{Z}$-sodium aluminum silicate hydrate $\mathrm{Na}_{96} \mathrm{Al}_{96} \mathrm{Si}_{96} \mathrm{O}_{384} 216 \mathrm{H}_{2} \mathrm{O}$ (39-222); N-sodium carbonate hydrate $\mathrm{Na}_{2} \mathrm{CO}_{3}\left(\mathrm{H}_{2} \mathrm{O}\right)$ (70-845); Hs-hydroxy-sodalite $\mathrm{Na}_{6}\left(\mathrm{AlSiO}_{4}\right)_{6} 8 \mathrm{H}_{2} \mathrm{O}$ (72-2329); $\mathrm{H}$-alcium aluminum hydroxide hydrate $\mathrm{Ca}_{2} \mathrm{Al}(\mathrm{OH})_{7} \cdot 3 \mathrm{H}_{2} \mathrm{O}(33-255)$. 
In the samples with higher amount of $\mathrm{SiO}_{2}$ the molar $\mathrm{SiO}_{2} / \mathrm{Na}_{2} \mathrm{O}$ ratio was 3. The peaks of new formed hydrates appear more intensive (Figure $5 b$ ). This could be related with formation of higher amount of polymerization products in alkali activated system. The hydroxy-sodalite was detected in the sample PGWG 15-3 [32].

Figure 6 shows the morphology of alkali activated biomass bottom ash after 28 days of hardening. PG 15-3 and PGWG 15-3 samples exhibited different microstructures. In the microstructure PG 15-3 sample varied honeycomb-like C-S-H and honeycomb type amorphous gel structures (Figure 6a) [33].

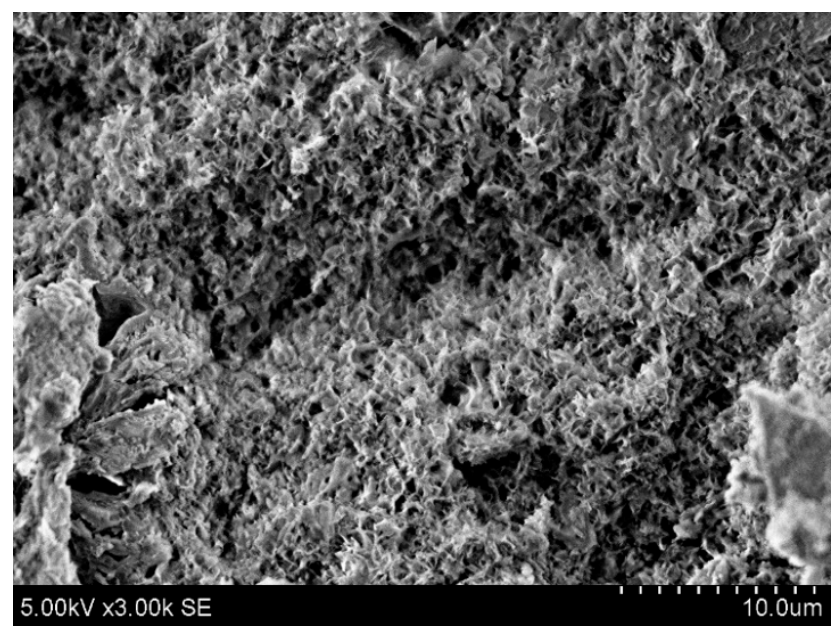

(a)

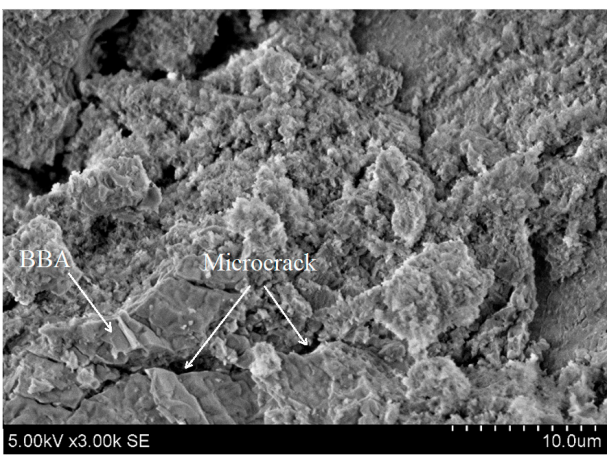

(b)

Figure 6. Microstructure of alkali activated biomass bottom ash samples (a) PG 15-3 and (b) PGWG 15-3.

It can be observed that in the PGWG 15-3 sample showed a higher degree of microcracking and unreacted the particle of BBA were detected as well (Figure 6b) [34]. This PGWG 15-3 sample had a more compact microstructure by comparing with the microstructure of PG 15-3 sample. This compact microstructure is closely related to the increased amount of hydration products which increased the amount of microcracks [35].

The compressive and flexural strength of alkali activated fine-grained concretes are shown in Table 4. As the aluminosilicate precursor the mixture of BBA with PG was used. The two types of alkali activator solutions were chosen: sodium hydroxide solution and the mixture of sodium hydroxide solution and sodium silicate hydrate. The proportions of PG and BBA were chosen according to the values of paste samples compressive strength (Figure 4). According to Ding et al. [36] the compressive strength values of the alkali-activated pastes, fine-grained concretes and concretes with the same pastes were unequal. Fine-grained concretes had significantly lower compressive strength compared with the paste samples.

Table 4. Compressive strength, flexural strength and density of alkali activated fine-grained concretes samples.

\begin{tabular}{|c|c|c|c|c|c|}
\hline \multirow{2}{*}{ Samples } & $\begin{array}{l}\text { Compressive } \\
\text { Strength, MPa }\end{array}$ & $\begin{array}{c}\text { Flexural } \\
\text { Strength, MPa }\end{array}$ & $\begin{array}{l}\text { Compressive } \\
\text { Strength, MPa }\end{array}$ & $\begin{array}{c}\text { Flexural } \\
\text { Strength, MPa }\end{array}$ & \multirow{2}{*}{$\begin{array}{c}\text { Density (After } \\
28 \text { Days), } \\
\text { kg/m } \mathrm{m}^{3}\end{array}$} \\
\hline & \multicolumn{2}{|c|}{ After 7 Days of Hardening } & \multicolumn{2}{|c|}{ After 28 Days of Hardening } & \\
\hline CPG 0-3 & $4.51 \pm 0.26$ & $1.52 \pm 0.05$ & $10.94 \pm 0.48$ & $2.30 \pm 0.12$ & $1965 \pm 14$ \\
\hline CPG 15-3 & $4.79 \pm 0.23$ & $2.22 \pm 0.06$ & $12.90 \pm 0.45$ & $2.31 \pm 0.15$ & $1971 \pm 14$ \\
\hline CPG 20-3 & $3.94 \pm 0.22$ & $1.39 \pm 0.06$ & $9.33 \pm 0.41$ & $2.00 \pm 0.17$ & $1853 \pm 15$ \\
\hline CPWG 0-3 & $6.42 \pm 0.28$ & $1.32 \pm 0.05$ & $10.73 \pm 0.42$ & $1.84 \pm 0.16$ & $1998 \pm 15$ \\
\hline CPWG 15-3 & $8.40 \pm 0.24$ & $2.18 \pm 0.08$ & $15.42 \pm 0.43$ & $2.41 \pm 0.11$ & $2019 \pm 14$ \\
\hline CPWG 20-3 & $6.20 \pm 0.27$ & $1.20 \pm 0.07$ & $11.94 \pm 0.31$ & $1.54 \pm 0.13$ & $1885 \pm 13$ \\
\hline
\end{tabular}


Chindaprasirt et al. [37] investigated and compared fly ash and bottom ash fine-grained concretes. The values of compressive strength are different for alkali activated fly ash and for bottom ash. Fly ash fine-grained concrete reached $35 \mathrm{MPa}$ while bottom ash fine-grained concrete had compressive strength in the range of 10-18 MPa. Such a difference is explained by the degree of polymerization. The polymerization of bottom ash is lower than the fly ash during alkali activation. All these samples were cured at $65{ }^{\circ} \mathrm{C}$ for $48 \mathrm{~h}$. In this work, samples were cured at lower $60^{\circ} \mathrm{C}$ temperature and duration was shorter- $24 \mathrm{~h}$. The fine-grained concretes samples had similar compressive strength $12.9 \mathrm{MPa}$ and 15.4 MPa when activated with $\mathrm{NaOH}$ solution and the mixture of $\mathrm{NaOH} / \mathrm{Na}_{2} \mathrm{SiO}_{3}$ solution, respectively (Table 4). The higher compressive strength could be related with the higher amount of active silicon (sodium silicate hydrate solution) [38]. The flexural strength was similar for both types of fine-grained concretes. A little bit higher value of flexural strength (2.4 MPa) were obtained for the sample with mixture of $\mathrm{NaOH}$ solution and $\mathrm{Na}_{2} \mathrm{SiO}_{3}$ solution (CPWG 15-3) compared with CPG 15-3 sample.

The porosity study is carried out on the two-alkali activated fine-grained concrete samples shown in Figure 7. It is considered to be because they are the ones that have shown the highest compressive strength values. The $\mathrm{X}$-ray diffraction study is carried out only on the 8 pastes because they are the ones that have shown the highest compressive strength values. The reference compositions were investigated as well. It is possible to predict the durability (freeze-thaw resistance) of alkali activated fine-grained concrete according to these parameters of porosity. The total porosity $(\mathrm{P})$ is almost the same for both types of fine-grained concretes. The open porosity $(\mathrm{Pa})$ which determined by water absorption of alkali activated fine-grained concrete was less (10.9\%) for CPG 15-3 samples compared with CPWG $15-3$ samples $13.4 \%$. Different situation is with close porosity (Pu). In this case CPG 15-3 samples had higher $16.8 \%$ close porosity compared with CPWG $15-3$ samples which had $14.1 \%$. Therefore, the alkali activator of $\mathrm{NaOH}$ and $\mathrm{Na}_{2} \mathrm{SiO}_{3}$ solutions had influence on the formation higher amount of close porosity and lower amount of open porosity while the total porosity remained the almost the same in activated fine-grained concrete samples. According to Nagrockiene et al. [39] concrete with higher closed porosity have better freeze-thaw resistance. Hence, the fine-grained concrete activated with the $\mathrm{NaOH}$ and $\mathrm{Na}_{2} \mathrm{SiO}_{3}$ solution should have higher freeze-thaw resistance compared with fine-grained concrete activated with just $\mathrm{NaOH}$ solution.

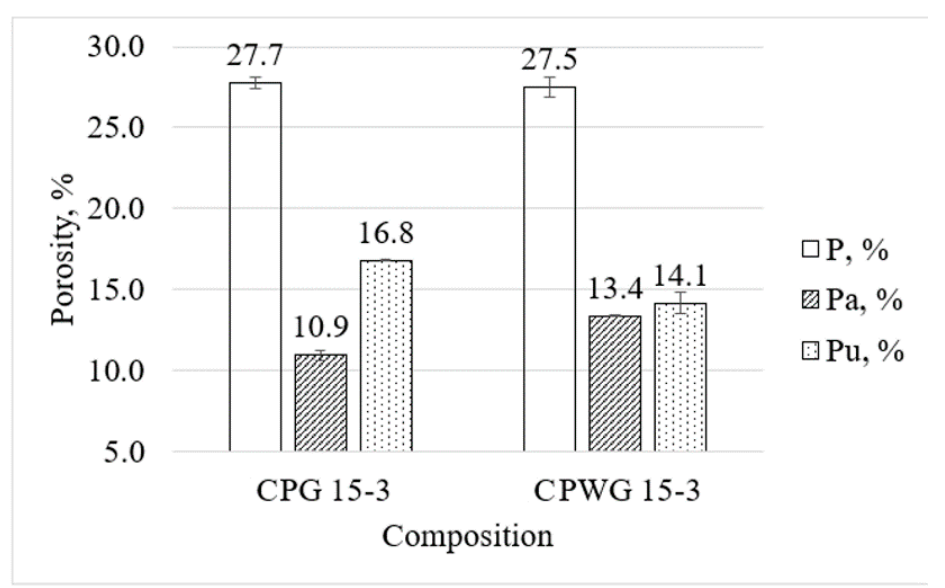

Figure 7. The porosity of alkali activated fine-grained concrete samples. P—total porosity; Pa—open porosity; $\mathrm{Pu}$-closed porosity.

\section{Conclusions}

In this study, the compressive strength of hardened alkali activated past and fine-grained concretes was determined. To improve the reaction degree of BBA calcium promoter such as PG was used. The following observation were made: 
- The higher values of compressive strength were detected when $\mathrm{SiO}_{2} / \mathrm{Na}_{2} \mathrm{O}$ molar ratio was three compared with the samples where samples had $\mathrm{SiO}_{2} / \mathrm{Na}_{2} \mathrm{O}=2$. When $\mathrm{SiO}_{2} / \mathrm{Na}_{2} \mathrm{O}$ molar ratio was two, the samples containing 20\% PG substitute had the highest compressive strength (24.3 MPa) after 28 days, while compressive strength of the samples with $\mathrm{SiO}_{2} / \mathrm{Na}_{2} \mathrm{O}$ molar ratio three peaked after 28 days at $30.0 \mathrm{MPa}$;

- Overall, paste samples activated with $\mathrm{NaOH} / \mathrm{Na}_{2} \mathrm{SiO}_{3}$ solution were weaker compared activated with $\mathrm{NaOH}$. The compressive strength peaked at $23.0 \mathrm{MPa}$ after seven days with $15 \%$ PG substitute, but after 28 days was reduced to $8.0 \mathrm{MPa}$. The reduction could be attributed to the cracking caused by the drying shrinkage. In addition, SEM images showed a higher degree of microcracking and unreacted the particle of $\mathrm{BBA}$ were detected when $\mathrm{NaOH} / \mathrm{Na}_{2} \mathrm{SiO}_{3}$ solution was activator;

- The amount of PG substitute was $15 \%-20 \%$ of BBA mass and it is recommended not to exceed $25 \%$. The higher amount of PG significantly reduced the compressive strength;

- In contrary to paste samples, fine-grained concrete samples have shown different tendencies. When BBA with $15 \%$ PG was activated with $\mathrm{NaOH} / \mathrm{Na}_{2} \mathrm{SiO}_{3}$ solution compressive strength reached 15.4 MPa after 28 days, but when the same precursors were activated with $\mathrm{NaOH}$ compressive strength was reduced by $16 \%(12.9 \mathrm{MPa})$. The higher compressive strength could be related with the higher amount of active silicon;

- Even though total porosity of fine-grained concrete activated by $\mathrm{NaOH}$ and $\mathrm{NaOH} / \mathrm{Na}_{2} \mathrm{SiO}_{3}$ solution was nearly the same $-27.5 \%$ and $27.7 \%$ respectfully, there is difference in open and closed porosity. When sodium silicate was present the open porosity was reduced from $16.8 \%$ to $14.1 \%$. Hence, the fine-grained concrete activated with the $\mathrm{NaOH}$ and $\mathrm{Na}_{2} \mathrm{SiO}_{3}$ solution should have higher freeze-thaw resistance;

- After 28 days of hydration the highest compressive strength reached $30.0 \mathrm{MPa}$ the samples activated $\mathrm{NaOH}$ solution and by using $15 \%$ of BBA substitution to PG. The possibility of potential use of BBA (silicon and aluminum sources) and PG (calcium source) as binder precursor for production of AAMs was confirmed. This can suggest a solution for both alkaline binders industry to provide a new precursor and fertilizers industry to solve the storage problems of PG.

Author Contributions: We all authors: D.V., D.N., A.K. (Aras Kantautas), V.B. and A.K. (Andrius Kielè) declare that we contributed to this article in equal parts about $20 \%$ everybody: D.V. and V.B. prepared the introduction part. Characterization of initial materials and the part of experimental procedures was prepared by D.N. and A.K. (Andrius Kielè). The parts of "Results and discussion" and "Conclusion" were written and evaluated by all authors. All authors have read and agreed to the published version of the manuscript.

Funding: This research received no external funding.

Acknowledgments: This research work was supported by the Lithuanian Science Council project "The utilization of industrial waste in alkali-activated concrete", project code P-MIP-17-363.

Conflicts of Interest: The authors declare no conflicts of interest.

\section{References}

1. Carrasco-Hurtado, B.; Corpas-Iglesias, F.A.; Cruz-Pérez, N.; Terrados-Cepeda, J.; Pérez-Villarejo, L. Addition of bottom ash from biomass in calcium silicate masonry units for use as construction material with thermal insulating properties. Constr. Build. Mater. 2014, 52, 155-165. [CrossRef]

2. Giergiczny, Z. Fly ash and slag. Cem. Concr. Res. 2019, 124, 105826. [CrossRef]

3. Nowoświat, A.; Gołaszewski, J. Influence of the variability of calcareous fly ash properties on rheological properties of fresh mortar with its addition. Materials 2019, 12, 1942. [CrossRef] [PubMed]

4. Wei, X.; Ming, F.; Li, D.; Chen, L.; Liu, Y. Influence of water content on mechanical strength and microstructure of alkali-activated fly ash/GGBFS mortars cured at cold and polar regions. Materials 2020, 13, 138. [CrossRef] 
5. Pérez-Villarejo, L.; Bonet-Martínez, E.; Eliche-Quesada, D.; Sánchez-Soto, P.J. Biomass bottom ash and aluminium industry slags-based geopolymers. In Vitrification and Geopolimerization of Wastes for Immobilization or Recycling, Proceedings of the Vitrogeowastes, Elche, Spain, 14-15 September 2017; Rincón, J.M., Vidal, M.J., Rincón, J.M., Vidal, M.J., Eds.; Universidad Miguel Hernández: Elche, Spain, 2017; Available online: http://innovacionumh.es/editorial/Vitrogeowastes.pdf (accessed on 15 September 2017).

6. Onori, R.; Will, J.; Hoppe, A.; Polettini, A.; Pomi, R.; Boccaccini, A.R. Bottom ash-based geopolymer materials: Mechanical and environmental properties. In Ceramic Engineering and Science Proceedings; Wiley: Hoboken, NJ, USA, 2011; Volume 32, pp. 71-82. [CrossRef]

7. ul Haq, E.; Padmanabhan, S.K.; Licciulli, A. Synthesis and characteristics of fly ash and bottom ash based geopolymers-A comparative study. Ceram. Int. 2014, 40, 2965-2971. [CrossRef]

8. Borg, R.P.; Briguglio, C.; Bocullo, V.; Vaičiukynienè, D. Preliminary investigation of geopolymer binder from waste materials. Rom. J. Mater. 2017, 47, 370-378.

9. Bocullo, V.; Vaičiukynienè, D.; Gečys, R.; Daukšys, M. Effect of ordinary portland cement and water glass on the properties of alkali activated fly ash concrete. J. Miner. 2020, 10, 1-10. [CrossRef]

10. JSC Lifosa, Ekstrakcinè fosforo rūgštis. Available online: https://www.lifosa.com/lt/ekstrakcine-fosfororugstis (accessed on 13 March 2020).

11. Mashifana, T.P. Chemical treatment of phosphogypsum and its potential application for building and construction. Proced. Manufact. 2019, 35, 641-648. [CrossRef]

12. Pérez-López, R.; Macías, F.; Cánovas, C.R.; Sarmiento, A.M.; Pérez-Moreno, S.M. Pollutant flows from a phosphogypsum disposal area to an estuarine environment: An insight from geochemical signatures. Sci. Total Environ. 2016, 553, 42-51. [CrossRef]

13. Gijbels, K.; Iacobescu, R.I.; Pontikes, Y.; Schreurs, S.; Schroeyers, W. Alkali-activated binders based on ground granulated blast furnace slag and phosphogypsum. Constr. Build. Mater. 2019, 215, 371-380. [CrossRef]

14. Rashad, A.M. Potential use of phosphogypsum in alkali-activated fly ash under the effects of elevated temperatures and thermal shock cycles. J. Clean. Prod. 2015, 87, 717-725. [CrossRef]

15. Vaičiukynienè, D.; Nizevičienè, D.; Kielè, A.; Janavičius, E.; Pupeikis, D. Effect of phosphogypsum on the stability upon firing treatment of alkali-activated slag. Constr. Build. Mater. 2018, 184, 485-491. [CrossRef]

16. Boonserm, K.; Sata, V.; Pimraksa, K.; Chindaprasirt, P. Improved geopolymerization of bottom ash by incorporating fly ash and using waste gypsum as additive. Cem. Concr. Comp. 2012, 34, 819-824. [CrossRef]

17. Khater, H.M.; Zedane, S.R. Geopolymerization of industrial by-products and study of their stability upon firing treatment. Int. J. Engineer. Technol. 2012, 2, 308-316.

18. Chang, J.J.; Yeih, W.; Hung, C.C. Effects of gypsum and phosphoric acid on the properties of sodium silicate-based alkali-activated slag pastes. Cem. Concr. Compos. 2005, 27, 85-91. [CrossRef]

19. Vaičiukynienè, D.; Nizevičienè, D.; Šeduikyte, L. Sustainable approach of the utilization of production waste: The use of phosphogypsum and AlF3 production waste in building materials. In Energy Efficient, Sustainable Building Materials and Products; Hager, I., Ed.; Wydawnictwo Politechniki Krakowskiej: Kraków, Poland, 2017; pp. 183-197.

20. Darsanasiri, A.G.N.D.; Matalkah, F.; Ramli, S.; Al-Jalode, K.; Balachandra, A.; Soroushian, P. Ternary alkali aluminosilicate cement based on rice husk ash, slag and coal fly ash. J. Build. Eng. 2018, 19, 36-41. [CrossRef]

21. Rajković, M.B.; Tošković, D.V. Phosphogypsum surface characterization using scanning electron microscopy. Acta Period. Technol. 2003, 34, 61-70. [CrossRef]

22. Bruker, D8 Advance Diffractometer (Bruker AXS) Technical Details. Available online: https://www. bruker.com/products/x-ray-difractionand-elemental-analysis/x-ray-difraction/d8-advance.html (accessed on 13 March 2020).

23. Bruker, X-ray S8 Tiger WD Series 2 Technical Details. Available online: https://www.bruker.com/products/xray-diffraction-andelemental-analysis/x-ray-fuorescence/s8-tiger.html (accessed on 13 March 2020).

24. Zeiss. EVO MA and LS Series Scanning Electron Microscopes for Materials Analysis and Life Science. Operator User Guide, Version 1.0; Zeiss: Cambridge, MA, USA, 2008.

25. CILAS, 1090 Particle Size Analyzer. Available online: https://www.pharmaceuticalonline.com/doc/cilas-1090particle-size-analyzer-0002 (accessed on 13 March 2020).

26. Girskas, G.; Skripkiūnas, G. The effect of synthetic zeolite on hardened cement paste microstructure and freeze-thaw durability of concrete. Constr. Build. Mater. 2017, 142, 117-127. [CrossRef] 
27. Topçu, İ.B.; Toprak, M.U.; Uygunoğlu, T. Durability and microstructure characteristics of alkali activated coal bottom ash geopolymer cement. J. Clean. Prod. 2014, 81, 211-217. [CrossRef]

28. Samantasinghar, S.; Singh, S. Effects of curing environment on strength and microstructure of alkali-activated fly ash-slag binder. Constr. Build. Mater. 2020, 235, 117481. [CrossRef]

29. Hanjitsuwan, S.; Phoo-ngernkham, T.; Damrongwiriyanupap, N. Comparative study using Portland cement and calcium carbide residue as a promoter in bottom ash geopolymer mortar. Constr. Build. Mater. 2017, 133, 128-134. [CrossRef]

30. Kovalchuk, G.; Fernández-Jiménez, A.; Palomo, A. Alkali-activated fly ash. Relationship between mechanical strength gains and initial ash chemistry. Mater. De Construcción 2008, 58, 35-52. [CrossRef]

31. Douglas, E.; Brandstetr, J. A preliminary study on the alkali activation of ground granulated blast-furnace slag. Cem. Concr. Res. 1990, 20, 746-756. [CrossRef]

32. Fernandez-Jimenez, A.; Monzo, M.; Vincent, M.; Barba, A.; Palomo, A. Alkaline activation of metakaolin-Fly ash mixtures: Obtain of Zeoceramics and Zeocements. Micropor. Mesopor. Mater. 2008, 108, 41-49. [CrossRef]

33. Karim, M.R.; Hossain, M.M.; Elahi, M.M.A.; Zain, M.F.M. Effects of source materials, fineness and curing methods on the strength development of alkali-activated binder. J. Build. Eng. 2020, 29, 101147. [CrossRef]

34. Santa, R.A.A.B.; Bernardin, A.M.; Riella, H.G.; Kuhnen, N.C. Geopolymer synthetized from bottom coal ash and calcined paper sludge. J. Clean. Prod. 2013, 57, 302-307. [CrossRef]

35. Gholampour, A.; Ho, V.D.; Ozbakkaloglu, T. Ambient-cured geopolymer mortars prepared with waste-based sands: Mechanical and durability-related properties and microstructure. Compos. Part. B Eng. 2019, 160, 519-534. [CrossRef]

36. Ding, Y.C.; Cheng, T.W.; Dai, Y.S. Application of geopolymer paste for concrete repair. Struct. Concr. 2017, 18, 561-570. [CrossRef]

37. Chindaprasirt, P.; Jaturapitakkul, C.; Chalee, W.; Rattanasak, U. Comparative study on the characteristics of fly ash and bottom ash geopolymers. Waste Manag. 2009, 29, 539-543. [CrossRef]

38. Huang, G.; Ji, Y.; Li, J.; Zhang, L.; Liu, X.; Liu, B. Effect of activated silica on polymerization mechanism and strength development of MSWI bottom ash alkali-activated mortars. Constr. Build. Mater. 2019, 201, 90-99. [CrossRef]

39. Nagrockienè, D.; Skripkiūnas, G.; Girskas, G. Predicting frost resistance of concrete with different coarse aggregate concentration by porosity parameters. Mater. Sci. 2011, 17, 203-207. [CrossRef]

(C) 2020 by the authors. Licensee MDPI, Basel, Switzerland. This article is an open access article distributed under the terms and conditions of the Creative Commons Attribution (CC BY) license (http://creativecommons.org/licenses/by/4.0/). 